The Art of Presence 



\title{
The Art of Presence
}

\section{The Poet and}

Paradise Lost

\author{
by Arnold Stein
}

UNIVERSITY OF CALIFORNIA PRESS

BERKELEY • LOS ANGELES - LONDON 
University of California Press

Berkeley and Los Angeles, California

University of California Press, Ltd.

London, England

Copyright $\odot 1977$ by

The Regents of the University of California

ISBN 0-520-02956-9

Library of Congress Catalog Card Number: 75-40668

Printed in the United States of America 
To

CHARLES S. SINGLETON

and to the Memory of DON CAMERON ALLEN 
